\title{
Habitat quality and prey size as determinants of survival in post-larval and early juvenile instars of the blue crab Callinectes sapidus
}

\author{
Robert J. Orth ${ }^{*}$, Jacques van Montfrans \\ School of Marine Science, Virginia Institute of Marine Science, College of William and Mary, Gloucester Point, \\ Virginia 23062, USA
}

\begin{abstract}
Habitat structure and prey size are important determinants in the outcome of predatorprey interactions. We investigated the role of simulated habitat type and density (simulated Zostera marina [hereafter referred to as 'Zostera']: 500 and 1500 shoots $\mathrm{m}^{-2}$, and simulated Spartina alterniflora [hereafter referred to as 'Spartina']: 97 and 291 shoots $\mathrm{m}^{-2}$ ) in mediating predator-prey interactions. Proportional survival during predation by the piscene predator Fundulus heteroclitus on 2 successive life-history stages (post-larvae and first juvenile instars) of the blue crab Callinectes sapidus (Rathbun), was quantified under laboratory conditions that closely approximated field conditions. We also examined the effects of juvenile crab size (equal biomass and equal numbers of 2 or 3 prey-size categories, respectively) on survival during adult $F$. heteroclitus predation in the absence of vegetation. Crab size categories included small (first juvenile instars; $2.1 \mathrm{~mm}$ carapace width [cw]), medium (fourth and fifth crab stage juveniles; 6.0 to $9.1 \mathrm{~mm} \mathrm{cw}$ ), and large (sixth and seventh stage juveniles; 9.2 to $12.6 \mathrm{~mm} \mathrm{cw}$ ) in the equal numbers experiments and small and medium crabs for the equal biomass experiment. Mean proportional survival was higher for both life-history stages in simulated Zostera, with first-instars exhibiting higher proportional survival than post-larvae at the experimental densities tested (post-larvae: no grass $=0.23$, low-density grass $=0.44$, high-density grass $=0.57$; first-instars: no grass $=0.47$, low-density grass $=0.87$, high-density grass $=0.87$ ). Mean proportional survival did not differ significantly among life-history stages in the simulated Spartina treatments, although proportional survival between treatments was higher for first-instars than post-larvae (postlarvae: no Spartina $=0.17$, low-density Spartina $=0.18$, high-density Spartina $=0.19$; first-instars: no Spartina $=0.46$, low-density Spartina = 0.43, high-density Spartina $=0.48$ ). Finally, size-refuge experiments with equal numbers or biomass of prey demonstrated significant differences between each size or/and biomass category tested. Crabs exhibited increasing proportional survival with increasing crab size $($ small $=0.34$, medium $=0.66$, large $=0.97)$ or weight $($ small $=0.18$, medium $=0.67)$ in the presence of $F$. heteroclitus, suggesting that $C$. sapidus attains a refuge in size from predation by adult F. heteroclitus at approximately 9.2 to $12.6 \mathrm{~mm}$. Our findings suggest that the influence of habitat structure on crab survival (possibly as a function of surface area) varies with simulated habitat type, crab density and crab stage (post-larvae versus first-instar), providing additional evidence of the importance of seagrasses in the early life-history stages of blue crabs.
\end{abstract}

KEY WORDS: Zostera $\cdot$ Spartina $\cdot$ Blue crab $\cdot$ Post-larvae $\cdot$ Juvenile instars $\cdot$ Post-larvae $\cdot$ Survival

\section{INTRODUCTION}

The ability of a prey species to avoid predation is a function of a complex set of temporally variable interactions involving behavior, size and density relationships

(C) Inter-Research $2002 \cdot$ www.int-res.com of predator and prey, and habitat quality (Main 1985, 1987, Sih 1985, 1987, Kneib 1995, Lipcius et al. 1998). The importance of habitat structure in ameliorating predation is complex (Bell et al. 1991). Structural quality associated with biological or physical attributes of 
the marine environment ranges from less complex structures, such as shell fragments or gravel (Sponaugle \& Lawton 1990), to highly complex systems like seagrass beds (Heck \& Crowder 1991). Such components of the habitat interact with the size and behavior of both prey and predator to ultimately determine the degree of prey survival (Paine 1976, Heck \& Crowder 1991, Rooker et al. 1998a).

Various habitats in estuaries and coastal lagoons, such as seagrass beds, salt marshes, macroalgae and oyster reefs, provide biogenic structure (Marx \& Herrnkind 1985, Orth \& van Montfrans 1990, Sogard \& Able 1991, Eggleston \& Armstrong 1995, Kneib 1995, Eggleston et al. 1998, Rooker et al. 1998b). These habitats support a diverse and dense assemblage of animals, and are generally considered critical nurseries for numerous species of vertebrates and invertebrates (Boesch \& Turner 1984, Kneib 1984, Orth et al. 1984, Rozas \& Minello 1998, Minello 1999, Beck et al. 2001). Structural complexity is determined by morphology, biomass, density, and the spatial configuration of these structural attributes, which influences habitat value (Stoner 1980, 1982, Rader 1984, Summerson \& Peterson 1984, Ryer 1988, Irlandi \& Peterson 1991, James \& Heck 1994, Lee \& Kneib 1994, Irlandi 1995, Irlandi et al. 1995).

Salt marshes (e.g. Spartina alterniflora) and submersed aquatic vegetation (e.g. Zostera marina) are 2 major structural components in the estuarine systems of North America. Several species, including the blue crab Callinectes sapidus, have been linked to these habitats (Minello 1999). The life cycle of the blue crab involves ontogenetic shifts in habitat use. After hatching, planktonic larvae (zoeae) develop through 7 to 8 stages on the nearshore continental shelf, eventually resulting in the post-larva (megalopa) stage. Megalopae reinvade coastal bays and estuaries (Rabalais et al. 1995, van Montfrans et al. 1995) and settle into shallow nursery habitats such as marsh and seagrass beds (Zimmerman \& Minello 1984, Orth \& van Montfrans 1987, 1990, Thomas et al. 1990, Heck \& Coen 1995, Kneib 1995, Morgan et al. 1996). Later-stage juveniles and adults re-distribute to different habitats based on size, sex, molt stage, salinity, and food availability (Hines et al. 1987, Mansour \& Lipcius 1991).

Quantitative sampling in a variety of shallow-water habitats along the latitudinal range of the blue crab (seagrass, mud, sand, marsh creeks) has demonstrated that abundance is significantly higher in structured (both marsh and seagrass) than unstructured habitats; among vegetated habitats, abundances are generally higher in seagrass beds (Heck \& Orth 1980a, Orth \& van Montfrans 1987, Mense \& Wenner 1989, Thomas et al. 1990, Wilson et al. 1990, Heck \& Coen 1995, Orth et al. 1996), although in the Gulf of Mexico densities can be higher in marsh than seagrass habitats (Rozas \& Minello 1998). In Chesapeake Bay, such abundance relationships hold true, particularly for early-instar juvenile crabs, which are often up to 2 orders of magnitude more abundant in seagrass beds than in adjacent marsh creeks or unvegetated habitats (Orth \& van Montfrans 1987).

Comparisons of first and second instar crab densities in a seagrass bed and marsh creek in Chesapeake Bay revealed an absence of these stages in the marsh creek and relatively high densities in the seagrass bed (Orth \& van Montfrans 1987), even though post-larvae were found to settle on artificial substrates placed in the marsh creek (R.J.O. \& J.v.M. unpubl. data). Third- and later instar crabs were increasingly more abundant in the marsh creek, although at significantly lower densities than in the adjacent seagrass bed. A reduction in the density of later-stage crabs (size range 11 to $25 \mathrm{~mm}$ carapace width) in the seagrass bed and increasing abundance in the marsh creek suggested that blue crabs may undergo shifts in habitat use triggered by attainment of a size refuge from predation (Orth \& van Montfrans 1987) analogous to those by juvenile spiny lobster, which shift from algae to sponges and finally to coral reefs or ledges (Smith \& Herrnkind 1992). Evidence from a field-tethering experiment in seagrass and adjacent unvegetated habitats which utilized firstthrough ninth-instar juvenile crabs demonstrated that predation rates diminished significantly between the fifth (size range 7.5 to $9.1 \mathrm{~mm}$ ) and ninth (14.2 to $16.1 \mathrm{~mm}$ ) juvenile instars (Pile et al. 1996).

We postulated that predation limits abundance of the earliest juvenile instars in marsh creek, and that laterstage crabs (larger than the third-instar, $4.25 \mathrm{~mm}$ ) increase in abundance due to movement of crabs from seagrass to the marsh creek coupled with a size refuge from predation as crabs grow larger. This study addresses 2 issues: survival of post-larvae and firstinstar crabs as a function of different densities of simulated habitat types (Zostera and Spartina), and the attainment of a refuge in size from predation in the absence of vegetation. Although seagrass and marsh creeks support a diverse number of predators to test these 2 issues, we chose the abundant benthic omnivore which is Fundulus heteroclitus, often found in both habitats.

\section{MATERIALS AND METHODS}

Animal collection. Callinectes sapidus post-larvae were collected from stationary plankton nets deployed during nighttime hours (Olmi 1995) from a pier located at the Virginia Institute of Marine Science, Gloucester Point. Post-larvae were collected immediately prior to 
experimentation and held in aerated aquaria until use (within $48 \mathrm{~h}$ ). First-instar and older juveniles were derived from plankton-collected megalopae that were subsequently held in the laboratory until metamorphosis to the first-juvenile instar. These were fed and grown to the size appropriate for experimentation.

Fundulus heteroclitus were collected using minnow traps placed in marsh creeks prior to conducting experiments. Fish (size range 80 to $100 \mathrm{~mm}$ standard length) were acclimated in aerated aquaria and fed live food from daily plankton collections supplemented with 'Purina' fish pellets. Fish were starved for $24 \mathrm{~h}$ prior to the initiation of each experiment. New predators were used for each experimental trial.

Laboratory experiments. All experiments described below were conducted in 1601 cylindrical fiberglass tanks $(42 \mathrm{~cm}$ high $\times 68 \mathrm{~cm}$ wide, area of bottom $=$ $0.36 \mathrm{~m}^{2}$ ). The tank bottoms were filled to approximately $4 \mathrm{~cm}$ with sieved beach sand (grain size $<1.0 \mathrm{~mm}$ ). Aeration of the tanks was adjusted to ensure a minimal water circulation considerably below the swimming capability of post-larvae (Luckenbach \& Orth 1992) and juvenile crabs. Upon termination of an experiment, the tank contents were sieved through a $1.0 \mathrm{~mm}$ sieve and the surviving animals were enumerated. Water and sediment were replaced between each experimental trial.

Expt 1. Effects of simulated habitat type and plant density on post-larvae and first-instar crab survival: We first tested the hypothesis that proportional survival of post-larvae and first-instar crabs was positively correlated with plant density. We used simulated habitat types to eliminate the complicating effects of alternative prey on live plants or leachates from live plants that might affect prey or predator behavior (Forward et al. 1994), and mimics that were most similar to the natural habitats we were testing: Zostera and Spartina. As simulated habitat types have been used frequently in marine ecological field (e.g. Eggleston et al. 1998) and laboratory (Gotceitas \& Colgan 1989, Nelson \& Bonsdorff 1990, Olmi \& Lipcius 1991, James \& Heck 1994) research over the past 2 decades, it seemed appropriate to use simulated habitats to investigate predatorprey interactions in our laboratory experiments.

Green polypropylene ribbon was used to simulate Zostera leaves, while green ribbon material inserted into translucent plastic soda straws was used to simulate bases of Spartina marsh shoots. The green ribbon simulated the color of epiphytic algae that grow along the bases of Spartina plants. We did not attempt to simulate the aerial portion of Spartina (i.e. the leaves), because organisms are unlikely to be exposed to any but the basal area of the shoots during high tide. Straws measuring $6 \mathrm{~mm}$ diameter $\times 34 \mathrm{~cm}$ long were used to simulate a marsh plant stalk. While not recre- ating all features of marsh plants, straws best mimic Spartina's most obvious habitat features and are similar to the wooden dowels $(6 \mathrm{~mm}$ diameter, $30 \mathrm{~cm}$ length) used by Nelson \& Bonsdorf (1990) to simulate Phragmites habitat in their predator-prey experiments.

Two shoot-density treatments were used in the experiments to provide an ecologically meaningful comparison of natural conditions: (1) low; low-density shoots similar to natural densities, (2) high; high-density shoots and 3 times denser than in the low-density treatment. We used data from Orth \& Moore (1986) for seagrass shoot density and width. Spartina shoot width and density were representative of plants from the York River system $\left(5.1 \mathrm{~mm}, 44\right.$ to 432 shoots $\mathrm{m}^{-2}$ width and density, respectively: R. N. Lipcius unpubl. data).

Low- and high-density $(3 \times)$ Spartina treatments comprised tanks with 35 shoots $\left(97\right.$ shoots $\mathrm{m}^{-2}$ ) and 105 shoots $\left(292\right.$ shoots $\mathrm{m}^{-2}$ ) per tank, respectively. Straws were inserted into the sand such that their tops extended above the water surface. The water depth was approximately $25 \mathrm{~cm}$. The straws were placed randomly in the tanks in groups of 3, 4, or 5 straws, reflecting natural clumping of Spartina shoots. Low-density treatments had 3 groups of 3 straws, 4 of 4 straws, and 2 of 5 straws. These conditions were increased 3 -fold in high-density treatments.

Low- and high-density (3x) Zostera treatments comprised tanks with 180 (500 shoots $\mathrm{m}^{-2}$ ) and 540 shoots (1500 shoots $\mathrm{m}^{-2}$ ) per tank, respectively. Simulated Zostera shoots were constructed with either 3 or 4 leaves (leaf width $=5 \mathrm{~mm}$ ), per shoot. Low-density treatments had 108 shoots with 4 leaves and 72 shoots with 3 leaves while in high-density treatments these parameters were increased 3-fold. Zostera shoots were constructed by tying the polypropylene ribbon to a plastic mesh mat buried under the sediment surface; simulated shoots extended to the water surface.

Prey densities represented the high range of natural densities for early juvenile crabs (Orth \& van Montfrans 1987) and post-larvae (R.J.O. \& J.v.M. unpubl. data). Thirty first-instar crabs and 60 post-larvae were used in the respective experiments.

We used 16 tanks in an experimental trial to test either simulated seagrass or marsh structure, with 4 tanks each randomly assigned to high-density, lowdensity, or no grass treatments, and controls (devoid of fish predators). Treatment assignments were re-randomized among tanks for each trial. Prior to each experiment, the tanks were filled with $1 \mu \mathrm{m}$-filtered estuarine water from the York River and allowed to acclimate to room temperature (approx. 22 to $24^{\circ} \mathrm{C}$ ) for $24 \mathrm{~h}$. Four separate trials $(\mathrm{n}=16$ for each of the 4 treatments) were conducted using post-larvae or first-instar crabs in simulated Zostera, while 2 trials ( $\mathrm{n}=8$ for each of the 4 treatments) were conducted in the simulated 


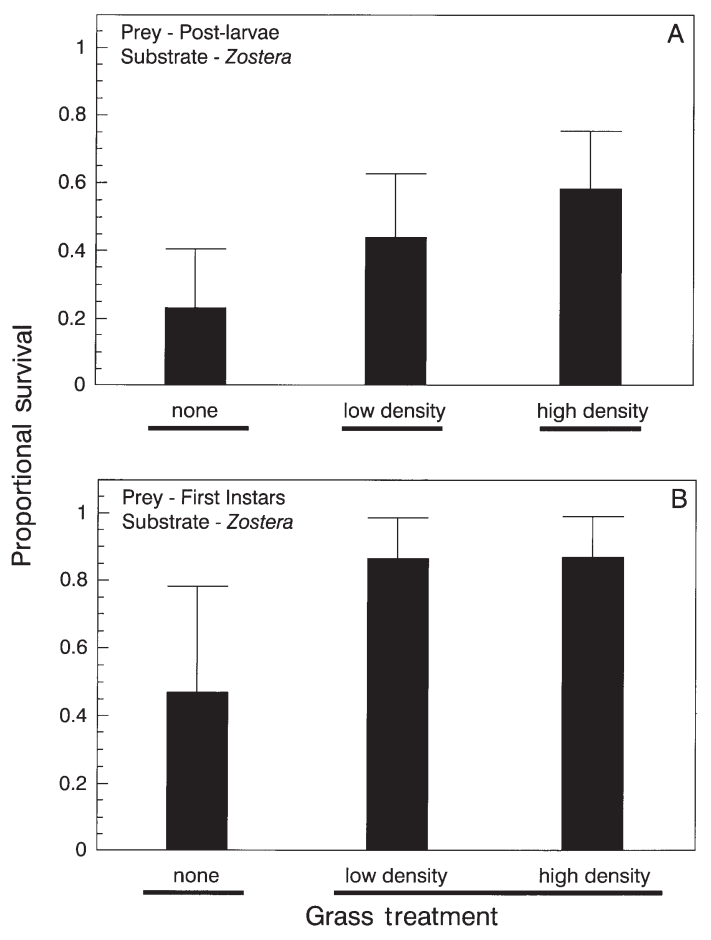

Fig. 1. Callinectes sapidus. Proportional survival (mean \pm $1 \mathrm{SD}$ ) of (A) post-larvae, and (B) first-instar blue crabs in the low- and high-density and in the no Zostera treatments. Horizontal lines below treatment designations indicate those treatments that are statistically similar

Spartina habitat. All experiments were conducted between 7 September and 4 October, 1988.

Experimental trials were commenced at $17: 30 \mathrm{~h}$ by placing either post-larvae or first-instar crabs into the tanks. Two Fundulus heteroclitus were placed in fine, plastic mesh baskets suspended in the tank overnight to allow predators and prey to acclimate to the experimental conditions while concurrently preventing the fish from foraging. The following morning at 05:00 $h$, the fish were released from the baskets and overhead fluorescent lights turned on at 06:00 h. The fish were allowed to forage for $8 \mathrm{~h}$ until termination of the experiment at 14:00 h. Substrates were carefully removed from the tanks at the conclusion of each experimental trial and rinsed in fresh water to ensure the collection of all remaining prey; fish were removed by dipnetting.

Exp 2. Crab-size effects on survival without habitat structure; equal numbers versus equal biomass: We tested the hypothesis that juvenile Callinectes sapidus attain a size refuge from predation by quantifying effects of Fundulus heteroclitus predation on different sizes of juvenile crabs in bare sand. Young-of-the-year crabs in 3 size classes, comprising 30 small (first-instar crabs $2.5 \mathrm{~mm}$ in carapace width), 30 medium (6.0 to $9.1 \mathrm{~mm}$ wide crabs equivalent to fourth- and fifth-in- star juveniles), and 30 large (9.2 to $12.6 \mathrm{~mm}$ wide individuals which reached the sixth- and seventh-juvenile instar) crabs were used as prey in 3 experimental trials. Crabs from the individual size categories were randomly assigned to 1 of 9 tanks, with each tank having only 1 size class; 2 predators were later added after acclimation procedures similar to those described above. Sampling protocols for this experiment ('equal numbers experiment') also followed those described above.

Subsequently, we tested the effect of predation on prey survival by using either small or medium crabs in separate treatments with the same total crab biomass (equal biomass experiment). We did not use large crabs because a high proportion of these survived in the equal numbers experiments. For both treatments, 3 replicates, utilizing either 80 small crabs or 10 medium crabs, were randomly assigned to 1 of 6 tanks containing sand substrate, to which 6 F. undulus heteroclitus were added after acclimation, as described earlier.

Statistical analysis. Two sets of analyses were run as follows:

Survival of post-larvae and first-instars in simulated Zostera and Spartina: After angular transformation to meet the assumption of homogeneity of variance, statistical analyses were made of the proportional survival of crabs. Analysis of variance was performed using simulated grass density as the main effect and trial as a blocking factor. Four separate analyses examined each combination of grass type (simulated Zostera and Spartina) and prey type (postlarvae and first-instar crabs). Ryan's $Q$ multiple-range test was used to make comparisons between levels of the main effect.

Survival under conditions of equal numbers and equal biomass of prey: Statistical analyses were performed on survival determined as the proportion of prey recovered from each experimental trial. Analysis of variance used prey size as the main effect and trial as a blocking factor. Separate analyses were made for each experiment (equal numbers and equal biomass). Ryan's $Q$ multiple-range test was used to make comparisons between levels of the main effect in each experiment.

\section{RESULTS}

\section{Survival of post-larvae and first-instars in simulated Zostera and Spartina trials}

The proportional survival of post-larvae and firstinstar crabs in the no-grass treatments for the simulated Zostera and Spartina tests was similar. This suggests that the following results were a function of simulated vegetation type and density. 


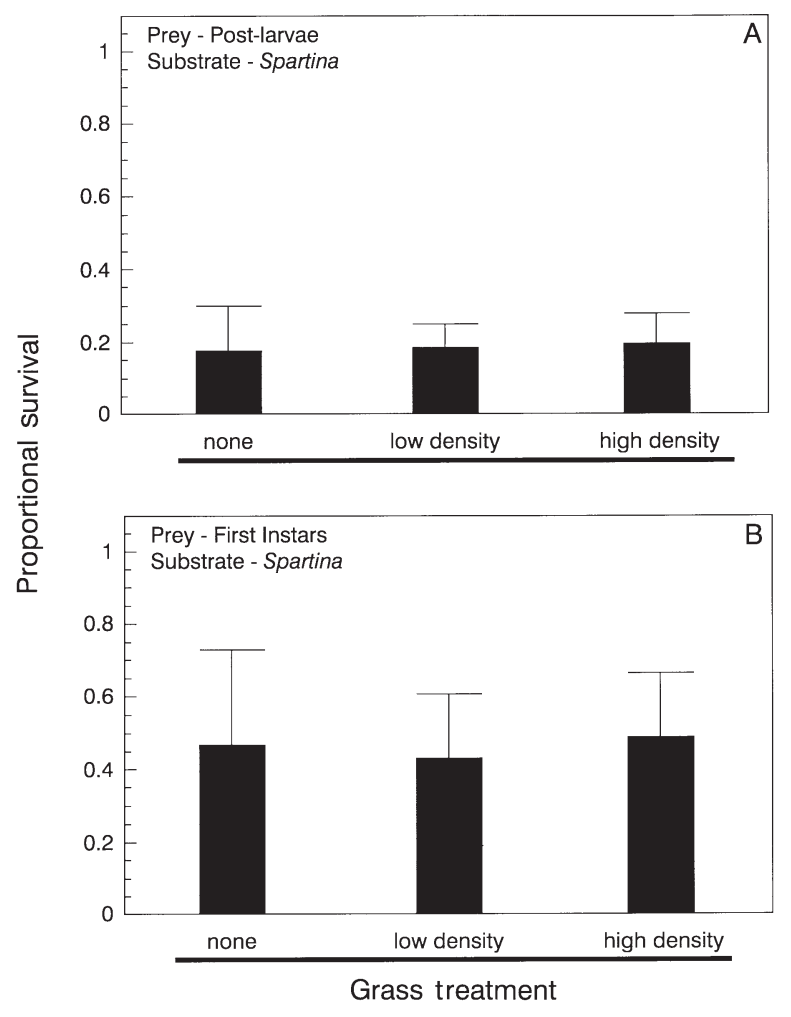

Fig. 2. Callinectes sapidus. Proportional survival (mean \pm $1 \mathrm{SD}$ ) of (A) post-larvae, and (B) first-instar blue crabs in the low- and high-density and in the no Spartina shoot treatments. Horizontal lines below treatment designations indicate those treatments that are statistically similar

In the simulated Zostera trials, proportional survival of post-larvae differed significantly among grass-density treatment levels (Fig. 1A) $(F=34.30$, df $=2,15, \mathrm{p}=$ $0.0001)$. Survival was highest in the high-density grass $(0.57)$ treatment, intermediate in the low-density $(0.44)$ treatment, and lowest in the no-grass treatment $(0.23)$.

The proportional survival of first-instar crabs also differed significantly among grass-density levels in the simulated Zostera trials (Fig. 1B) $F=21.31$, df $=2,15$, $\mathrm{p}=0.0001)$, with survival in low-density grass $(0.87)$ similar to that in high-density treatments $(0.87)$ but differing significantly from the no-grass treatment (0.47). Survival of crabs in the controls averaged 0.96 for all simulated Zostera trials.

In the simulated Spartina treatments, proportional survival of both post-larvae and first-instar crabs did not differ significantly among shoot-density treatment levels (Fig. 2) (post-larvae: $F=0.21$, df $=2,15, \mathrm{p}=$ 0.8111; first-instar crabs: $F=0.12, \mathrm{df}=2,15, \mathrm{p}=0.8870$ ). Survival in the no-, low- and high-Spartina shoot treatments was $0.17,0.18$, and 0.19 for post-larvae, and $0.46,0.43$, and 0.48 for first-instar crabs, respectively.
Crab survival in the controls averaged 0.97 for all simulated Spartina trials.

\section{Survival under conditions of equal numbers and equal biomass of prey}

The proportional survival of crabs differed significantly among the 3 size classes in the equal numbers experiment (Fig. 3A) $(F=17.60, \mathrm{df}=2,8, \mathrm{p}<0.0001)$. Survival was greatest for large crabs $(0.97)$, lower for intermediate-sized crabs (0.66), and lowest for small crabs (0.34). The survival of crabs in the controls averaged 0.97 for all 3 sizes.

In the equal biomass experiments, proportional survival differed significantly (Fig. 3B) $(F=14.77, \mathrm{df}=1,5$, $p=0.018$ ) between small and medium-sized crabs being greatest for the medium-sized class (0.67) and lowest for the small-sized class (0.18). Proportional survival of crabs in the controls averaged 0.93 and 0.96 for the medium and small crabs, respectively.

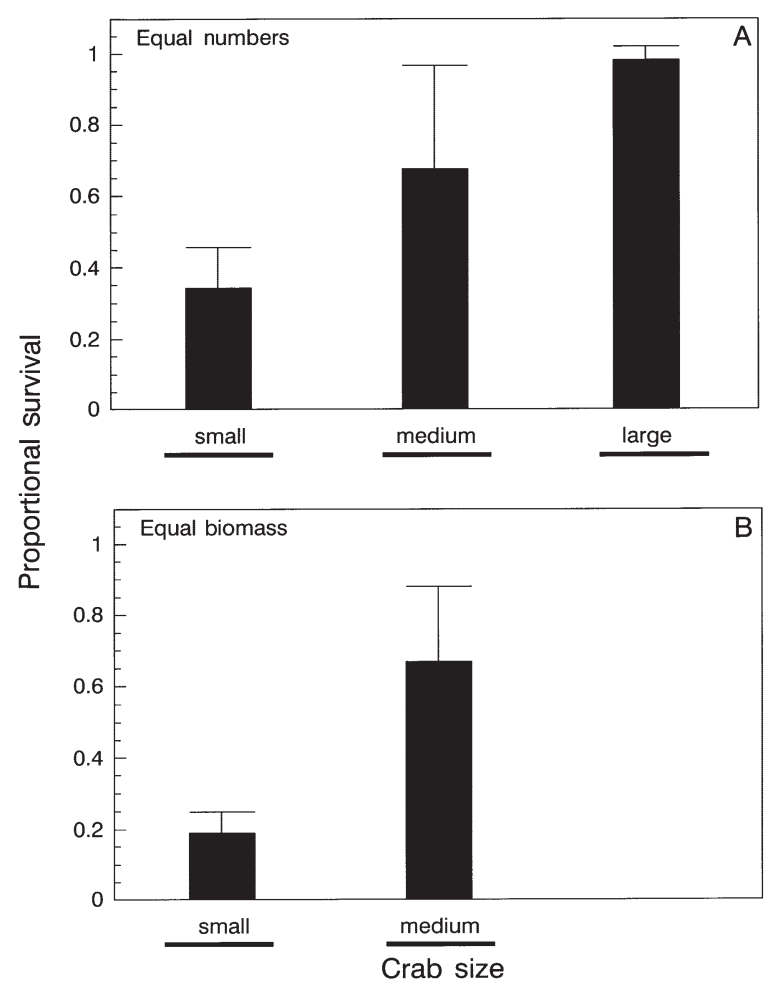

Fig. 3. Callinectes sapidus. Proportional survival in (A) equal numbers experiment for 3 different crab sizes (small = $2.5 \mathrm{~mm}$; medium $=6.0$ to $9.1 \mathrm{~mm}_{\text {; }}$ large $=9.2$ to $12.6 \mathrm{~mm}$ ), and (B) equal biomass experiment for 2 different crab sizes $($ small $=2.5 \mathrm{~mm}$; medium $=6.0$ to $9.1 \mathrm{~mm})$. Horizontal lines below treatment designation indicate those treatments that are statistically similar 


\section{DISCUSSION}

Differential survival of early life-history stages of the blue crab appears to depend upon both life-history stage (post-larvae vs first-instars) and habitat, thereby supporting earlier perspectives on habitat-specific size distribution patterns documented in nature (Orth \& van Montfrans 1987). Whereas our findings corroborate those of other predator-prey investigations regarding the importance of habitat structure and prey size as determinants of prey survival (Heck \& Crowder 1991, Rooker at al 1998a, Stunz \& Minello 2001), we also have demonstrated that life-history stage significantly influences predator-prey dynamics.

Although simulated seagrass reduced predation in both post-larvae and first-instar crabs, no refuge was afforded crabs by the simulated marsh shoots for either life-history stage. In addition, proportional survival in the simulated seagrass treatments was higher than in the simulated marsh treatments for each of the 2 plantdensity treatments. The absence of any refuge in the simulated marsh structure was surprising, but may in

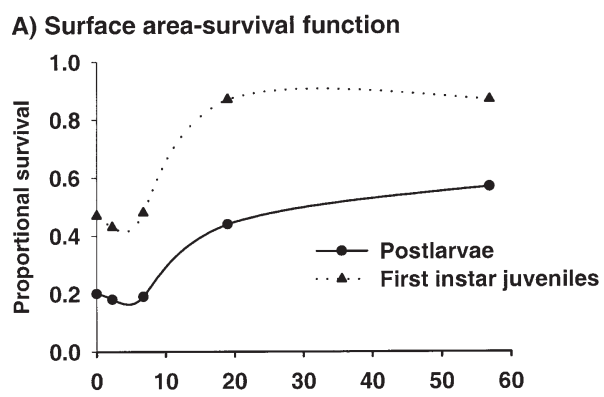

B) Surface area - survival rate change function

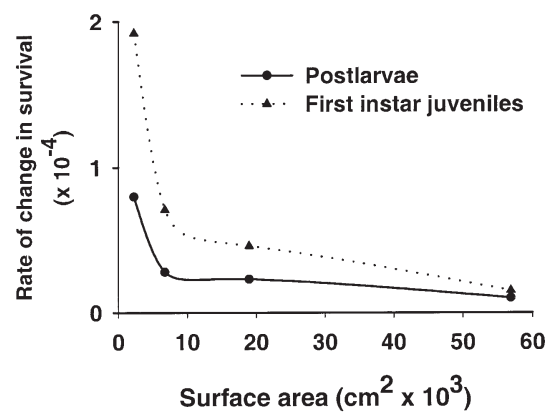

Fig. 4. Callinectes sapidus. Post-hoc analysis of (A) survival and (B) survival rate change of post-larvae and first-juvenile instars as a function of treatment surface area (sensu Lipcius et al. 1998). Prey survival is directly related to increased surface area, whereby the rate of change in survival ( $B$, first derivative) decreases with increasing surface area and converges at the highest value tested. (Note that in A, control survival at a surface area of 0 falls on the $y$-axis followed by the 2 Spartina and Zostera surface area values, respectively; these data are confounded by treatment: see 'Discussion') part explain some of the abundance patterns noted in our field sampling. While first-stage instars were generally abundant in the seagrass habitat, we rarely found them in the marsh creek habitat (Orth \& van Montfrans 1987). Although post-larvae are known to enter the marsh area we sampled on nighttime flood tides (R.J.O. \& J.v.M. unpubl. data), neither post-larvae nor early juvenile stages were found in pit traps deployed among Spartina alterniflora shoots on the marsh surface. The absence or paucity of these lifehistory stages in $S$. alterniflora marshes may be due to increased risk of predation in these habitats. Thomas et al. (1990) and Rozas \& Minello (1998) also found fewer small crabs in marsh habitats compared to nearby seagrass beds.

The differences in surface area between simulated seagrass and marsh may be a confounding influence that could also explain some of the differences in proportional survival. We attempted to reproduce natural plant densities in our experimental treatments, although the total surface area of Spartina, even in the highest-density treatment, was approximately 3 times lower than that simulated by the low density Zostera treatment. Prey survival appears to be a function of quantifiable habitat structure such as biomass (Lipcius el al. 1998) or surface area. The first derivative of the relationship illustrates the consequences of predator-prey dynamics (Lipcius et al. 1998). A post-hoc examination of our results suggests that the surface area of various treatments may have influenced survival of both post-larvae and first-instar juvenile crabs (Fig. 4). Proportional survival was low for post-larvae (approx. 0.20) in the 3 lowest surface area treatments $\left(0,2244\right.$, and $\left.6731 \mathrm{~cm}^{2}\right)$, increasing by more than 2-fold (0.44 and 0.57) in the highest surface-area treatments $\left(18965\right.$ and $\left.56894 \mathrm{~cm}^{2}\right)$, although these results were confounded by habitat type (low survival was associated with the low surface area of the simulated Spartina treatments, and higher survival with the increased surface area of the simulated Zostera treatments) (Fig. 4A).

Although the same treatment biases apply to firstinstar crabs, these displayed a similar relationship with lowest survival (0.43 to 0.47 ) in the 3 lowest surface area (zero and Spartina) treatments and an almost 2fold increase in survival (0.87) in the highest density Zostera treatments (Fig. 4A). Survival of both post-larvae and first-instar juvenile crabs followed a similar pattern, although juvenile crabs exhibited a higher overall survival with increasing surface area than did post-larvae (Fig. 4A). Furthermore, the rate of change in survival for both post-larvae and first-instar juvenile crabs decreased with increasing surface area and converged at the highest surface area tested $\left(56894 \mathrm{~cm}^{2}\right.$ : Fig. 4B). These data suggest a possible threshold effect of surface area on survival (Heck \& Orth 1980b, Got- 
ceitas \& Colgan 1989, Nelson \& Bonsdoff 1990, Heck \& Crowder 1991), although definitive resolution of such patterns awaits more experimentation.

Despite the absence of a refuge benefit for post-larvae and first-instar crabs in the simulated marsh plants in the present study, blue crabs are abundant both as post-larvae and juveniles in marshes along the Atlantic and Gulf coasts, where seagrasses are absent or rare (e.g. South Carolina [Mense \& Wenner 1989], Georgia [Wrona et al. 1995], Louisiana [Zimmerman \& Minello 1984]). Recent studies suggest that factors other than a refuge from predation may be important in determining prey abundances, e.g. density-dependent processes, marsh physiography, various physical factors (e.g. frequency and duration of tidal inundation) and their biological interactions (Kneib 1984, 1995, Zimmerman \& Minello 1984, Orth \& van Montfrans 1990, Rozas \& Minello 1998, Minello 1999, Cicchetti \& Diaz 2000). However, in experimental mesocosms, Stunz \& Minello (2001) found that more structurally complex habitats such as oyster shell and seagrasses provided young red drum Sciaenops ocellatus with more protection than did Spartina alterniflora. Perhaps features of structure such as surface area are the contributing factors in the refuge value of various habitats for associated species.

On sand bottoms, the proportional survival from predation by Fundulus heteroclitus increased with increasing crab size in both the equal numbers and equal biomass experiments. A size refuge was attained at about 12 to $15 \mathrm{~mm}$ carapace width (sixth- and seventhinstar crabs), a size refuge that is smaller than that postulated earlier (Orth \& van Montfrans 1987) or indicated by field-tethering experiments (Pile et al. 1996). However, our results are based on the restricted conditions imposed by the experimental laboratory setting, whereby 1 predator species with a limited gape was allowed to feed on 3 size categories of blue crab prey in the absence of a structured habitat. We would expect the size at which a prey attains a refuge from natural predation to be a function of the foraging strategy and gape size of the predator (Heck \& Orth 1980b, Ryer 1988), behavioral responses of the prey in the presence of the predator (Main 1985, 1987), and characteristics of the habitat (e.g. degree of fragmentation [Hovel \& Lipcius 2001], distance from shoreline or other habitats such as marsh [Micheli \& Peterson 1999, Raposa \& Oviatt 2000], and aspects of habitat structure, e.g. leaf width, biomass, or surface area [Ryer 1988, Lipcius et al. 1998, Rooker et al 1998a, Attrill et al. 2000]). Rooker et al. (1998a) found mortality rates for juvenile red drum lower in a seagrass habitat than over bare sand, and that mortality from predation decreased with increasing prey size in both habitat types.

Olmi \& Lipcius (1991) found no effect of simulated Zostera marina on the survival of blue crab post-larvae in the presence of both sand shrimp Crangon septemspinosa and grass shrimp Palaemonetes pugio. The lack of effect may have been the smaller containers used by Olmi \& Lipcius compared to those used in our experiments $\left(0.06 \mathrm{~m}^{2}\right.$ vs $\left.0.36 \mathrm{~m}^{2}\right)$, the relatively longer experimental period ( $40 \mathrm{~h}$ vs $8 \mathrm{~h}$ ), and the lower simulated Zostera shoot density (145 shoots $\mathrm{m}^{-2}$ [surface area $=175 \mathrm{~cm}^{2}$ ] vs 500 shoots $\mathrm{m}^{-2}$ [surface area $=$ $\left.18965 \mathrm{~cm}^{2}\right]$ ), coupled with differences in the foraging strategies of the predators used.

Factors affecting the survival of early juvenile blue crabs may be similar to those influencing the survival and distribution of other species with complex life cycles (Roughgarden et al. 1988) exhibiting strong swimming capabilities. Pueruli (post-larvae) of the spiny lobster Panuliris argus settle in structurally complex macroalgae, remain there for several months while foraging, and thereafter shift to small crevices or other cover during daytime (Marx \& Herrnkind 1985, Herrnkind \& Butler 1986, Marx 1986). Algal-dwelling juveniles are extremely susceptible to predation, while slightly larger juveniles emerging from the settlement habitat attain a partial size refuge from predation (Herrnkind \& Butler 1986, Smith \& Herrnkind 1992) similar to that seen for blue crabs. Dungeness crabs Cancer magister, which recruit into oyster shells as post-larvae from offshore plankton and have strong swimming abilities, may exhibit similar ontogenetic shifts once they have gained a refuge in size in oyster-shell areas (Fernandez et al. 1993, 1994, Eggleston \& Armstrong 1995).

Our experiments provide additional evidence for the importance of seagrasses in the survival of post-larval and juvenile blue crabs, possibly as a result of increased surface area (Stoner 1980, Stoner \& Lewis 1985). For the blue crab, the value of seagrass as a refuge may be restricted to a relatively narrow range of crab sizes (in this study from the post-larvae to the first-instar juvenile). If surface area is important, then management efforts should focus on increasing habitats that provide the greatest surface area to benefit associated fauna. However, other structural features of seagrassess (e.g. blade width: Ryer 1988, Rooker et al. 1998a) have also been shown to influence the survival of other animals, so multiple features of habitat complexity may need to be considered in habitat protection and enhancement programs. If vegetated areas (or other structured habitats featuring similar levels or types of complexity) comprise higher quality refuges producing disproportionately greater numbers of individuals that enter the adult population relative to other habitats (i.e. the concept of the nursery area defined by Beck et al. 2001), management efforts should focus on implementing strategies to preserve and/or enhance these nursery habitats and the extrinsic variables (e.g. water quality: Dennsion et al. 1993) that ultimately determine their long-term survival. 
Acknowledgements. This work was supported by the National Sea Grant College Program of the National Oceanic and Atmospheric Administration, Department of Commerce, under Grant No. NA-90AA-D-SG-045, to the Virginia Graduate Marine Science Consortium and the Virginia Sea Grant College Program. We gratefully acknowledge the valuable contributions of the following people: C. Ryer for all phases of the work, K. Metcalf for statistical assistance, J. Nowak, S. Mauger, and H. Neckles for laboratory assistance, and J. Fishman, S. Marion, and R. Lipcius for providing valuable comments on the manuscript. Contribution No. 2458 from the Virginia Institute of Marine Science, School of Marine Science, College of William and Mary.

\section{LITERATURE CITED}

Attrill MJ, Strong JA, Rowden AA (2000) Are macroinvertebrate communities influenced by seagrass structural complexity? Ecography 23:114-121

Beck MW, Heck KL Jr, Able KW, Childers DL and 9 others (2001) Towards better identification, conservation, and management of estuarine and marine nurseries for fish and invertebrates. BioScience 51:633-641

Bell SS, McCoy ED, Mushinsky HR (1991) Habitat structure: the physical arrangement of objects in space. Chapman \& Hall, New York

Boesch DF, Turner RE (1984) Dependence of fishery species on salt marshes: the role of food and refuge. Estuaries 7 : $460-468$

Cicchetti G, Diaz RJ (2000) A dynamic budget model of energy flow from infauna to nekton in a polyhaline Virginia salt marsh. In: Weinstein M, Kreeger DA (eds) Concepts and controversies in tidal marsh ecology. Kluwer Academic Publishers, Dordrecht, p 515-541

Dennison WC, Orth RJ, Moore KA, Stevenson JC, Carter V, Kollar S, Bergstrom PW, Batiuk RA (1993) Assessing water quality with submersed aquatic vegetation. BioScience 43 : 86-94

Eggleston D, Armstrong DA (1995) Pre and post-settlement determinants of estuarine dungeness crab recruitment. Ecol Monogr 65:193-216

Eggleston D, Etherington LL, Elis WE (1998) Organism response to habitat patchiness: species and habitat-dependent recruitment of decapod crustaceans. J Exp Mar Biol Ecol 223:111-132

Fernandez M, Iribarne O, Armstrong D (1993) Ecdysial rhythms in megalopae and first-instars of the dungeness crab Cancer magister. Mar Biol 118:661-615

Fernandez M, Iribarne O, Armstrong D (1994) Swimming behavior of dungeness crab, Cancer magister Dana, megalopae in still and moving water. Estuaries 17:271-275

Forward RB Jr, Frankel DAZ, Rittschof D (1994) Molting of megalopae from the blue crab Callinectes sapidus: effects of offshore and estuarine cues. Mar Ecol Prog Ser 113: $55-59$

Gotceitas V, Colgan P (1989) Predator foraging success and predator-prey interactions: quantitative test of the threshold hypothesis. Oecologia 80:158-166

Heck KL Jr, Coen LD (1995) Predation and the abundance of blue crabs: a comparison of selected East and Gulf Coast (USA) studies. Bull Mar Sci 57:877-883

Heck KL Jr, Crowder LB (1991) Habitat structure and predator-prey interactions in vegetated aquatic systems. In: Bell SS, McCoy ED, Mushinsky HR (eds) Habitat structure, the physical arrangements of objects in space. Chapman \& Hall, New York, p 281-299
Heck KL Jr, Orth RJ (1980a) Structural components of eelgrass (Zostera marina) meadows in the lower Chesapeake Bay-decapod crustacea. Estuaries 3:289-295

Heck KL Jr, Orth RJ (1980b) Seagrass habitats: the roles of habitat complexity, competition and predation in structuring associated fish and motile macroinvertebrate assemblages. In: Kennedy VS (ed) Estuarine perspectives. Academic Press, New York, p 449-464

Herrnkind WF, Butler MJ IV (1986) Factors regulating postlarval settlement and juvenile microhabitat use by spiny lobsters Panuliris argus. Mar Ecol Prog Ser 34:23-30

Hines AH, Lipcius RN, Haddon AM (1987) Population dynamics and habitat partitioning by size, sex, and molt stage of blue crabs Callinectes sapidus in a subestuary of central Chesapeake Bay. Mar Ecol Prog Ser 36:55-64

Hovel KA, Lipcius, RN (2001) Habitat fragmentation in a seagrass landscape: patch size and complexity control blue crab survival. Ecology 82:1814-1829

Irlandi EA (1995) Large- and small-scale effects of habitat structure on rates of predation: how percent coverage of seagrasses affects rates of predation and siphon nipping on an infaunal bivalve. Oecol 98:176-183

Irlandi EA, Peterson CH (1991) Modification of animal habitat by large plants: mechanisms by which seagrasses influence clam growth. Oecol 87:307-318

Irlandi EA, Ambrose WG, Orlando BA (1995) Landscape ecology and the marine environment: how spatial configuration of seagrass habitat influences growth and survival of the bay scallop. Oikos 72:307-313

James PL, Heck KL Jr (1994) The effects of habitat complexity and light intensity on ambush predation within a simulated seagrass habitat. J Exp Mar Biol Ecol 176: $187-200$

Kneib RT (1984) Patterns of invertebrate distribution and abundance in the intertidal salt marsh: causes and questions. Estuaries 7:392-412

Kneib RT (1995) Behavior separates potential and realized effects of decapod crustaceans in salt marsh communities. J Exp Mar Biol Ecol 193:239-256

Lee SY, Kneib RT (1994) Effects of biogenic structure on prey communities by xanthid crabs Eurytium limosum and Panopeus herbstii in a salt marsh. Mar Ecol Prog Ser 104: $39-47$

Lipcius RN, Eggleston DB, Miller DL, Luhrs TC (1998) The habitat-survival function for Caribbean spiny lobster: an inverted size effect and non-linearity in mixed algal and seagrass habitats. Mar Freshw Res 49:807-816

Luckenbach MW, Orth RJ (1992) Swimming velocities and behavior of blue crab (Callinectes sapidus Rathbun) megalopae in still and flowing water. Estuaries 15:186-192

Main KL (1985) The influence of prey identity and size on selection of prey by two marine fishes. J Exp Mar Biol Ecol 88:145-152

Main KL (1987) Predator avoidance in seagrass meadows: prey behavior, microhabitat selection, and cryptic coloration. Ecol 68:170-180

Mansour RA, Lipcius RN (1991) Density dependent foraging and mutual interference in blue crabs preying on infaunal clams. Mar Ecol Prog Ser 72:239-246

Marx JM (1986) Recruitment and settlement of spiny lobster pueruli in south Florida. Can J Fish Aquat Sci 43: 2221-2227

Marx JM, Herrnkind WF (1985) Macroalgae (Rhodophyta: Laurencia spp) as a habitat for young juvenile spiny lobsters, Panuliris argus. Bull Mar Sci 36:423-431

Mense DJ, Wenner EL (1989) Distribution and abundance of early life-history stages of the blue crab, Callinectes 
sapidus, in tidal marsh creeks near Charleston, South Carolina. Estuaries 12:157-168

Micheli F, Peterson CH (1999) Estuarine vegetated habitats as corridors for predator movements. Conserv Biol 13: $869-881$

Minello TJ (1999) Nekton densities in shallow estuarine habitats of Texas and Louisiana and the identification of essential fish habitat. Am Fish Soc Symp 22:43-75

Morgan SG, Zimmer-Faust RK, Heck KL Jr, Coen LD (1996) Population regulation of blue crabs, Callinectes sapidus, in the northern Gulf of Mexico: postlarval supply. Mar Ecol Prog Ser 133:73-88

Nelson WG, Bonsdorff E (1990) Fish predation and habitat complexity: are complexity thresholds real? Exp Mar Biol Ecol 141:183-194

Olmi EJ III (1995) Ingress of blue crab megalopae in the York River, Virginia, 1987-1989. Bull Mar Sci 57:753-780

Olmi EJ III, Lipcius RN (1991) Predation on post-larvae of the blue crab Callinectes sapidus Rathbun by sand shrimp Crangon septemspinosa Say and grass shrimp Palaemonetes pugio Holthuis. J Exp Mar Biol Ecol 151:169-183

Orth RJ, Moore KA (1986) Seasonal and year-to-year variations in the growth of Zostera marina L. (eelgrass) in the lower Chesapeake Bay. Aquat Bot 24:335-341

Orth RJ, van Montfrans J (1987) Utilization of a seagrass meadow and tidal marsh creek by blue crabs Callinectes sapidus. I. Seasonal and annual variations in abundance with emphasis on post-settlement juveniles. Mar Ecol Prog Ser 41:283-294

Orth RJ, van Montfrans J (1990) Utilization of marsh and seagrass habitats by early stages of Callinectes sapidus: a latitudinal perspective. Bull Mar Sci 46:126-144

Orth RJ, Heck KL Jr, van Montfrans J (1984) Faunal communities in seagrass beds: a review of the influence of plant structure and prey characteristics on predator-prey relationships. Estuaries 7:339-350

Orth RJ, van Montfrans J, Lipcius RN, Metcalf KS (1996) Utilization of seagrass habitat by the blue crab, Callinectes sapidus Rathbun: a review. In: Kuo J, Phillips RC, Walker DI, Kirkman H (eds) Seagrass biology: Proceedings of an International Workshop. Western Australian Museum, Perth, p 213-224

Paine RT (1976) Size-limited predation: an observational and experimental approach with the Mytilus-Pisaster interaction. Ecol 57:858-873

Pile A, Lipcius RN, van Montfrans J, Orth RJ (1996) Densitydependent settler-recruit-juvenile relationships in blue crabs. Ecol Monogr 66:277-300

Rabalais NN, Burditt FR Jr, Coen LD, Cole BE, Eleuterius C, Heck KL Jr, McTigue TA, Morgan SG, Perry HM, Truesdale FM, Zimmer-Faust RK, Zimmerman RJ (1995) Settlement of Callinectes sapidus megalopae on artifical collectors in four Gulf of Mexico Estuaries. Bull Mar Sci 57: 855-876

Rader DN (1984) Salt-marsh benthic invertebrates: smallscale patterns of distribution and abundance. Estuaries 7 : $413-420$

Raposa KB, Oviatt CA (2000) The influence of contiguous shoreline type, distance from shore and vegetation biomass on nekton community structure in eelgrass beds. Estuaries 23:46-55

Rooker JR, Holt GJ, Holt SA (1998a) Vulnerability of newly settled red drum (Sciaenops ocellatus) to predatory fish: is

Editorial responsibility: Kenneth Heck (Contributing Editor), Dauphin Island, Alabama, USA early life-life survival enhanced by seagrass meadows? Mar Biol 131:145-151

Rooker JR, Holt SA, Soto MA, Holt GJ (1998b) Postsettlement patterns of habitat use by sciaenid fishes in subtropical seagrass meadows. Estuaries. 21:318-327

Roughgarden J, Gaines SD, Possingham H (1988) Recruitment dynamics in complex life cycles. Science 241: $1460-1466$

Rozas LP, Minello TJ (1998) Nekton use of salt marsh, seagrass, and unvegetated habitats in a south Texas (USA) estuary. Bull Mar Sci 63:481-501

Ryer CH (1988) Pipefish foraging: effects of fish size, prey size and altered habitat complexity. Mar Ecol Prog Ser 48: $37-45$

Sih A (1985) Evolution, predator avoidance, and unsuccessful predation. Am Nat 125:153-157

Sih A (1987) Predators and prey lifestyles: an evolutionary and ecological overview. In: Kerfoot WC, Sih A (eds) Predation: direct and indirect impacts on aquatic communities. University Press of New England, Hanover, $\mathrm{NH}_{4}$ p 203-224

Smith KN, Herrnkind WF (1992) Predation on the early juvenile spiny lobsters Panuliris argus (Latreille): influence of size and shelter. J Exp Mar Biol Ecol 157:3-18

Sogard SM, Able KW (1991) A comparison of eelgrass, sea lettuce macroalgae, and marsh creeks as habitats for epibenthic fishes and decapods. Estuar Coast Shelf Sci 33: 501-519

Sponaugle S, Lawton P (1990) Portunid crab predation on juvenile hard clams: effects of substrate type and prey density. Mar Ecol Prog Ser 66:43-53

Stoner AW (1980) Perception and choice of substratum by epifaunal amphipods associated with seagrass. Mar Ecol Prog Ser 3:105-111

Stoner AW (1982) The influence of benthic macrophytes on the foraging behavior of pinfish, Lagodon rhomboides (Linnaeus). J Exp Mar Biol Ecol 58:271-284

Stoner AW, Lewis FG III (1985) The influence of quantitative and qualitative aspects of habitat complexity in tropical sea-grass meadows. J Exp Mar Biol Ecol 94:19-40

Stunz GW, Minello TJ (2001) Habitat-related predation on juvenile wild-caught and hatchery-reared red drum $\mathrm{SCi}_{-}$ aenops ocellatus (Linnaeus). J Exp Mar Biol Ecol 260: $13-25$

Summerson HC, Peterson CH (1984) Role of predation in organizing benthic communities of a temperate-zone seagrass bed. Mar Ecol Prog Ser 15:63-77

Thomas JL, Zimmerman RJ, Minello TJ (1990) Abundance patterns of juvenile blue crabs (Callinectes sapidus) in nursery habitats of two Texas bays. Bull Mar Sci 46: $115-125$

van Montfrans J, Epifanio CE, Knott DM, Lipcius RN and 7 others (1995) Settlement of blue crab post-larvae in western north Atlantic estuaries. Bull Mar Sci 57:834-854

Wilson KA, Able KW, Heck KL Jr (1990) Habitat use by juvenile blue crabs: a comparison among habitats in southern New Jersey. Bull Mar Sci 46:105-114

Wrona AB, Wiegert RG, Bishop TD (1995) Initial report of settlement patterns of brachyuran megalopae at Sapelo Island, Georgia, USA. Bull Mar Sci 57:807-820

Zimmerman RJ, Minello TJ (1984) Densities of Penaeus aztecus, Penaeus setiferus, and other natant macrofauna in a Texas salt marsh. Estuaries 7:421-433

Submitted: May 9, 2000; Accepted: October 22, 2001

Proofs received from author(s): March 29, 2002 